\title{
ADULT STATURE RECONSTRUCTION FROM CEPHALO-FACIAL DIMENSION IN INDIAN FEMALES
}

Kamil Khan ${ }^{1}$ Md Tabrej Alam *2 Srivastava RK ${ }^{3}$ Kalpana Purohit ${ }^{4}$ Md Shadab Raheel ${ }^{5}$.

${ }^{1}$ Assistant Professor, Department of Anatomy, Hind Institute of Medical Sciences, Sitapur, UP (India).

*2 Assistant Professor, Department of Anatomy, Hind Institute of Medical Sciences, Sitapur, UP (India).

${ }^{3}$ Professor, Department of Anatomy, Hind Institute of Medical Sciences, Sitapur, UP (India)

${ }^{4}$ Assistant Professor, Department of Anatomy, Hind Institute of Medical Sciences, Sitapur, UP (India).

${ }^{5}$ Assistant Professor, Department of Forensic Medicine and Toxicology, FH Medical College, Agra, UP (India).

\section{ABSTRACT}

Aim: To identify the Stature from the cephalo-facial dimension (facial height) in Indian females.

Materials and Methods: A stadiometer was used to measure the stature, and the facial height was taken by utilizing a vernier caliper, in 43 female medical students. To know about the significance and correlation, the data were analysed statistically.

Results: Mean stature and the mean facial height were found to be $158.93 \pm 11.06 \mathrm{~cm}$ and $10.39 \pm 0.83 \mathrm{~cm}$ respectively. $P$ value was less than 0.001 and Pearson's coefficient obtained was 0.93 . Hence, there is found to be a significant positive correlation between stature and facial height in Indian females.

Conclusion: Estimation of stature from the facial height could be performed where only unknown head and face are brought for anthropometric examinations.

KEY WORDS: Facial Height, Stature, Cephalofacial dimension.

Address for Correspondence: Dr. Md Tabrez Alam, Assistant Professor, Department of Anatomy, Hind Institute of Medical Sciences, Sitapur, UP (India), Pin Code-261303

mobile: (+91)9690125881, 7007281391 E-Mail: dr.kamilkhan@gmail.com

Access this Article online

Quick Response code

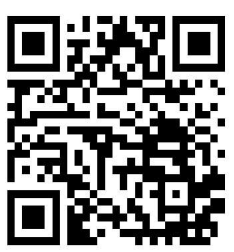

DOI: $10.16965 /$ ijar.2018.129

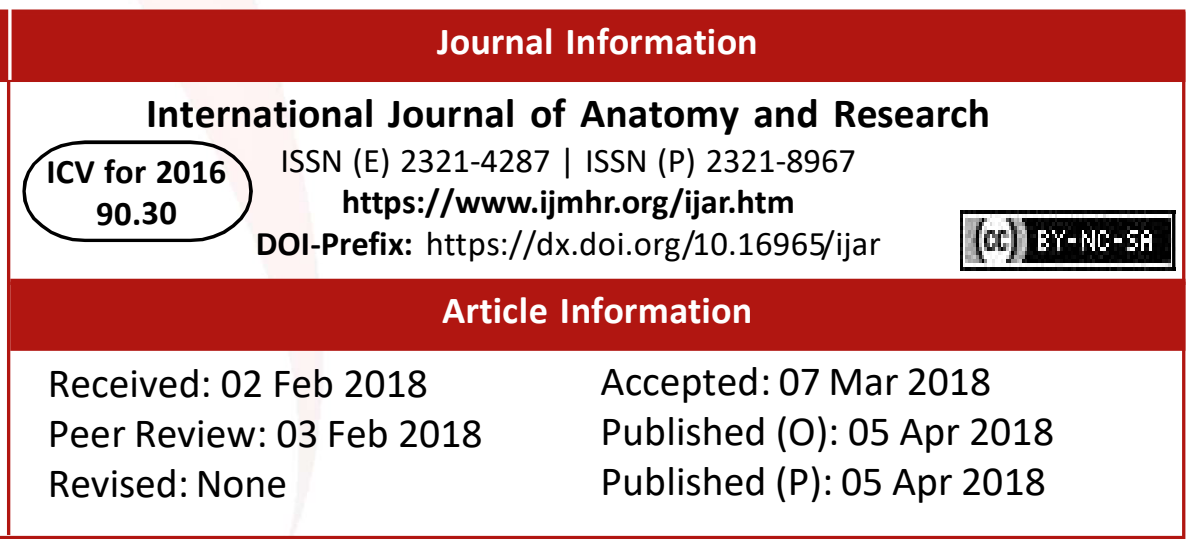

\section{INTRODUCTION}

Personal identification is grit of uniqueness of a person. Personal identification is of two types i.e. complete (absolute) and incomplete (partial). Complete identification is an absolute fixation of individuality of a person. Knowing only some particulars regarding the identity of an individual is partial identification. One of the primary characteristics of identification is Stature [1].

Cephalo-Facial Dimensions are the different parameters of the head and face. One of the important Cephalo-Facial Dimension is Facial 
height [2]. Stature or Height is a very much important anthropometric parameter in the personal details of any individual. Many anthropometric studies have been performed to establish the relationship between stature and length of the long bones and other body dimensions such as arm length. However, studies that correlate facial height and stature are uncommon [3].

Anthropometric techniques have been applied to find body size for more than a hundred years. With an increase in mass disasters, the identification of the stature of the person became quite a difficult task [4].

Earlier, researchers have utilized many bones of human skeleton such as long bones to short bones to find the stature of a person. They found that even from the smallest bone the stature can be estimated. Fragments of the long bones have been used by some scientists for the estimation of stature [5].

Some authors have done studies from various parts of the body like upper and lower limbs, hands, trunk and intact vertebral column for the estimation of stature. Foot and footprints, individual long and short bones have been utilized for estimation of stature by another group of scientists. But only a few researches have been done on cephalofacial dimensions of the facial height with respect to estimating the stature [6-12].

\section{MATERIALS AND METHODS}

The present study was conducted in the department of Anatomy at Hind Institute of Medical Sciences, Sitapur UP (India). A total of 43 female medical students participated in this study as subjects. Their age was between 18 to 25 years. Subjects with the history of abnormal neurological findings affecting the facial dimensions, oculofacial trauma and craniofacial deformities were excluded from the study.

Inclusion criteria: Subjects with age between 18-25 years, Healthy adults without any skeletal deformities like dwarfism or gigantism, Subjects were able to stand in an erect posture without any spinal or muscular pathology.

Exclusion criteria: Subjects with spinal deformities like kyphosis, lordosis and scoliosis,
Subjects with facial deformities that can affect facial height, Individuals with craniofacial deformities(congenital or acquired), Individuals with abnormal neurological findings (such as facial palsy, ptosis and squint)

Equipments used in the study: Stadiometer, Vernier calliper, Digital camera.

Somatometric Parameters: Stature, Facial Height Stature and Facial Height are calculated for the subjects according to the benchmark anthropometric methods of the global Society for the development of Kin anthropometry [13]. Informed consents were taken from the subjects. The (anthropometric variables) facial height and the stature were measured.

Definition of Stature: It is the distance from the plane where the individual stands to the vertex (the highest point on the head when the head is in eye ear plane). The individual should be in erect posture [14].

Procedure for measurement of Stature (Fig. 1): Stature is calculated to the adjacent 0.1 centimetres in bare feet with the individual standing erect against stadiometer. The subjects head has to be in the Frankfort horizontal plane. This is obtained when the inferior rim of the orbit is parallel with the tragion (A point in the depth of notch just above the tragus of the ear). The subjects are said to stand straight with his heel in concert and his backs in a straight line as achievable in order that his head, shoulders, buttocks and heels touch the rod of stadiometer. The arms are hanging liberally by the sides. Asking the subject to take a deep breath and hold it, interpretations are taken from the stadiometer scale at his vertex point. The subject is then told to breathe and to step away from the floor of stadiometer [15].

Definition of Facial Height: The distance from the nasion (the nasal root) to the gnathion (the lowest point on the lower border of the mandible in the mid sagittal plane) [16].

\section{Procedure for measurement of Facial Height}

(Fig. 2): The subject was asked to sit on a chair with the head facing forward. From nasion to gnathion, the two sliding ends of the vernier caliper were placed. The vernier caliper was then removed from the face and the facial height was recorded in the nearest $\mathrm{mm}$, which is the 
straight distance from the nasion to the gnathion [17].

Data obtained were interpreted using SPSS software v. 20 and descriptive statistic was used. Pearson's coefficient and unpaired student-t test were used to describe the correlation and to compare the means respectively. $P$ value less than 0.05 was considered to be statistically significant.

\section{RESULTS}

Our study was conducted on 43 female medical students. The subjects mean age was $21.34 \pm$ 1.29 years. The sample size is shown in table 1 .

Table 2 depicts mean values ( $\pm S D$ ), minimum and maximum values of stature and facial height of adult females of the Indian population. In the sample of 43 , the adult females have an average stature of $(158.93 \pm 11.06) \mathrm{cm}$ and the mean Facial Height was found to be $(10.39 \pm 0.83) \mathrm{cm}$.

Table 3 shows Karl Pearson's correlation coefficient between the stature and the facial height in adult females of the Indian population.

Therefore, there is a statistically significant positive correlation ( $p<0.001$ and Pearson's coefficient ' $r$ ' $=0.93$ ) between the stature and the facial height as shown above in table 3.

Fig. 1: Method of Measuring the Stature.

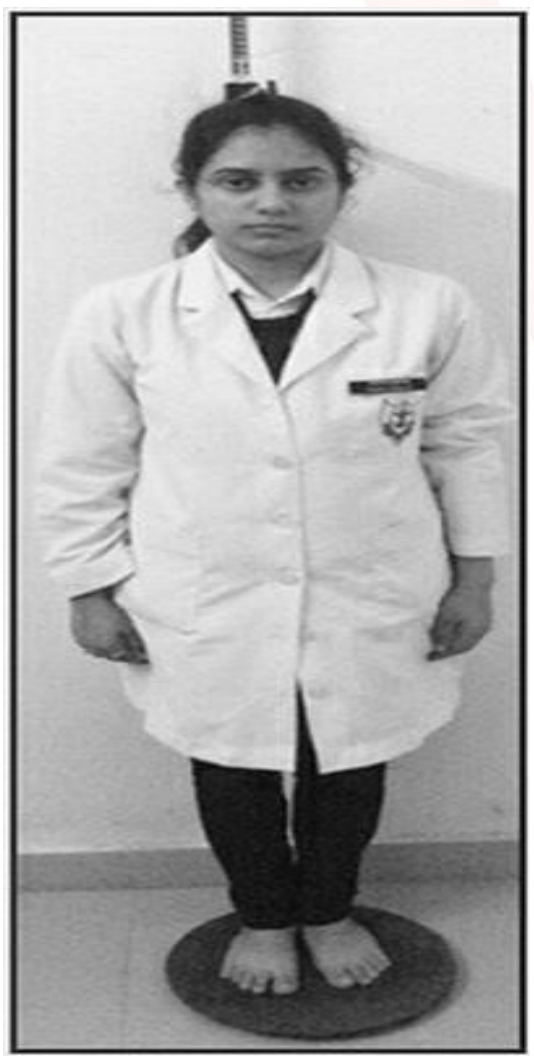

Int J Anat Res 2018, 6(2.1):5104-09. ISSN 2321-4287
Fig. 2: Method of Taking the Facial.

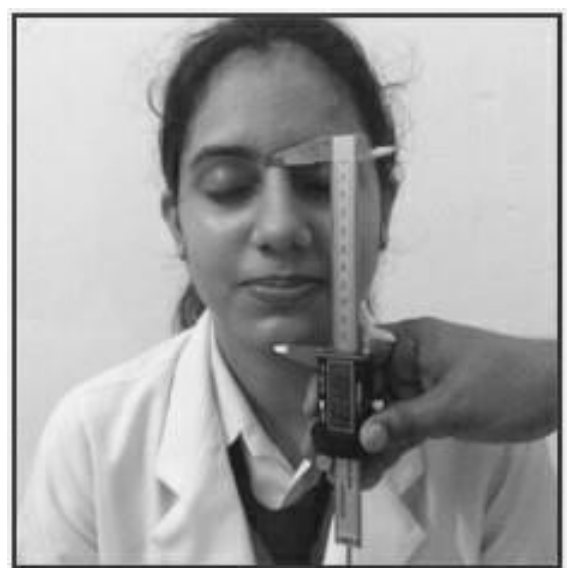

Table 1: Sample size.

\begin{tabular}{|c|c|c|}
\hline Sample & $\begin{array}{c}\text { No. of } \\
\text { Subjects }\end{array}$ & Mean Age (Years) \\
\hline $\begin{array}{c}\text { Medical Female } \\
\text { Students }\end{array}$ & 43 & $21.34 \pm 1.29$ \\
\hline
\end{tabular}

Table 2: Description of different variables.

\begin{tabular}{|c|c|c|c|c|c|}
\hline \multirow{2}{*}{ Variables } & \multirow{2}{*}{ sex } & \multirow{2}{*}{ Mean \pm SD } & \multirow{2}{*}{ S.E.M } & \multicolumn{2}{|c|}{ Range } \\
\cline { 5 - 6 } & & & & Min. & Max. \\
\hline Stature $(\mathrm{cm})$ & $\mathrm{F}$ & $158.93 \pm 11.06$ & 1.686 & 130 & 180 \\
\hline Facial Height $(\mathrm{cm})$ & $\mathrm{F}$ & $10.39 \pm 0.83$ & 0.126 & 4.7 & 7.3 \\
\hline
\end{tabular}

Table 3: Correlation statistics of stature with facial height.

\begin{tabular}{|c|c|c|}
\hline $\begin{array}{c}\text { Correlation of } \\
\text { Stature with }\end{array}$ & $\begin{array}{c}\text { Pearson's } \\
\text { coefficient }(r)\end{array}$ & P-value \\
\hline Facial height & 0.93 & $<0.001$ \\
\hline
\end{tabular}

Table 4: Researches showing mean facial height more than the mean of the present study.

\begin{tabular}{|c|c|c|c|}
\hline \multirow{2}{*}{ Authors } & Population & Sex & $\begin{array}{c}\text { Facial Height } \\
\text { (cm) }\end{array}$ \\
\hline \multirow{2}{*}{ Farkas et al., (2005) } & Azerbaijan & $\mathrm{F}$ & 11.16 \\
\cline { 2 - 4 } & Singaporean Chinese & $\mathrm{F}$ & 11.49 \\
\cline { 2 - 4 } & Vietnamese & $\mathrm{F}$ & 11.31 \\
\cline { 2 - 4 } & Thai & $\mathrm{F}$ & 11.28 \\
\cline { 2 - 4 } & Japanese & $\mathrm{F}$ & 11.38 \\
\hline Patil \& Mody (2005) & $\begin{array}{c}\text { Central Indian } \\
\text { population }\end{array}$ & $\mathrm{F}$ & 11.16 \\
\hline Sahni et al., (2010) & $\begin{array}{c}\text { Northwest Indian } \\
\text { Population }\end{array}$ & $\mathrm{F}$ & 10.11 \\
\hline Aghnihotri et al.,(2011) & $\begin{array}{c}\text { Indo-Mauritian } \\
\text { Population }\end{array}$ & $\mathrm{F}$ & 11 \\
\hline Hossain (2011) & $\begin{array}{c}\text { Japanese (1975-79) } \\
\text { \& (1998-2001) }\end{array}$ & $\mathrm{F}$ & 11.44 \\
\hline Wankhede et al., (2012) & $\begin{array}{c}\text { Nagpur Medical } \\
\text { college students }\end{array}$ & $\mathrm{F}$ & 10.66 \\
\hline Present Study & $\begin{array}{c}\text { Sitapur Medical } \\
\text { College Students }\end{array}$ & $\mathrm{F}$ & 10.38 \\
\hline
\end{tabular}


Table 5: Researches showing mean facial height less than present study.

\begin{tabular}{|c|c|c|}
\hline Researcher & Population & $\begin{array}{c}\text { Facial Height } \\
(\mathrm{Cm})\end{array}$ \\
\hline Krishan \& Kumar (2007) & North Indian Kolis & 10.24 \\
\hline Krishan (2008) & Haryanvi Baniyas & 10.07 \\
\hline Present Study & $\begin{array}{c}\text { Sitapur Medical } \\
\text { College Students }\end{array}$ & 10.38 \\
\hline
\end{tabular}

Table 6: Researches showing comparison of mean stature of previous studies with present study.

\begin{tabular}{|c|c|c|}
\hline Researchers & Population & $\begin{array}{c}\text { Mean Stature } \\
\text { (cms) }\end{array}$ \\
\hline Patil \& Mody (2005) & $\begin{array}{c}\text { Central Indian } \\
\text { Populations }\end{array}$ & 150.55 \\
\hline Ryan\& Bidmos (2007) & $\begin{array}{c}\text { Indigenous South } \\
\text { Africans }\end{array}$ & 143.08 \\
\hline Kalia et al., (2008) & Mysorean patients & 155.67 \\
\hline Sahni et al., (2010) & Northwest Indians & 163.24 \\
\hline Akhter et al., (2010) & Bangladeshi & 152.79 \\
\hline Ilayperuma (2011) & Srilankans & 152.48 \\
\hline Agnihotri et al., (2011) & $\begin{array}{c}\text { Indo-Mauritian } \\
\text { Populations. }\end{array}$ & 157.36 \\
\hline Asha and Prabha (2011) & $\begin{array}{c}\text { South Indian } \\
\text { Populations } \\
\text { North Indian } \\
\text { Populations }\end{array}$ & 156.82 \\
\hline Wankhede et al., (2012) & $\begin{array}{c}\text { Medical students of } \\
\text { Nagpur }\end{array}$ & 156.39 \\
\hline Present Study & $\begin{array}{c}\text { Medical students of } \\
\text { Sitapur }\end{array}$ & 158.93 \\
\hline
\end{tabular}

\section{DISCUSSION}

The obtained results show that we can estimate stature from facial height in cases where unknown human remains are brought for anthropometric investigations. With respect to age, sex and race absolute dimensions and bodily proportions vary among individuals. Body Stature has been estimated from various other parameters of the body. In the identification of persons, these parameters are of very much importance. The stature of an individual is genetically predetermined and is an inherent feature $[3,5]$.

Estimation of the stature in these cases can also be helpful to identify the other personal data like estimation of sex, race and age [18].

In the present study, facial height has been measured and related with stature. The positive correlation between the facial height and stature in Indian study population (Pearson's
Table 7: Comparison of correlation coefficients between stature and facial height of previous studies with present study.

\begin{tabular}{|c|c|c|c|}
\hline Researchers & Population & $\begin{array}{c}\text { Correlation } \\
\text { coefficient (r) }\end{array}$ & P-value \\
\hline Patil \& Mody (2005) & $\begin{array}{c}\text { Central Indian } \\
\text { Population }\end{array}$ & ---- & $<0.01$ \\
\hline Jibon \& Lilancnandra (2006) & $\begin{array}{c}\text { Kabuis of Imphal } \\
\text { Valley }\end{array}$ & ---- & --- \\
\hline Krishan \& Kumar (2007) & North Indian Kolis & ---- & ---- \\
\hline Krishan (2008) & North Indian Gujjars & ---- & --- \\
\hline Sahni et al., (2010) & North west Indians & 0.181 & 0.021 \\
\hline Pelin et al., (2010) & Turkish Population & ----- & ---- \\
\hline Agnihotri et al., (2011) & $\begin{array}{c}\text { Indo -Mauritian } \\
\text { Population }\end{array}$ & 0.164 & $<0.001$ \\
\hline Wankhede et al., (2012) & $\begin{array}{c}\text { Medical Students of } \\
\text { Nagpur }\end{array}$ & 0.144 & 0.001 \\
\hline Present study & $\begin{array}{c}\text { Medical } \\
\text { Students of Sitapur }\end{array}$ & 0.928 & 0.002 \\
\hline
\end{tabular}

Graph 1: Correlation between stature and facial height.

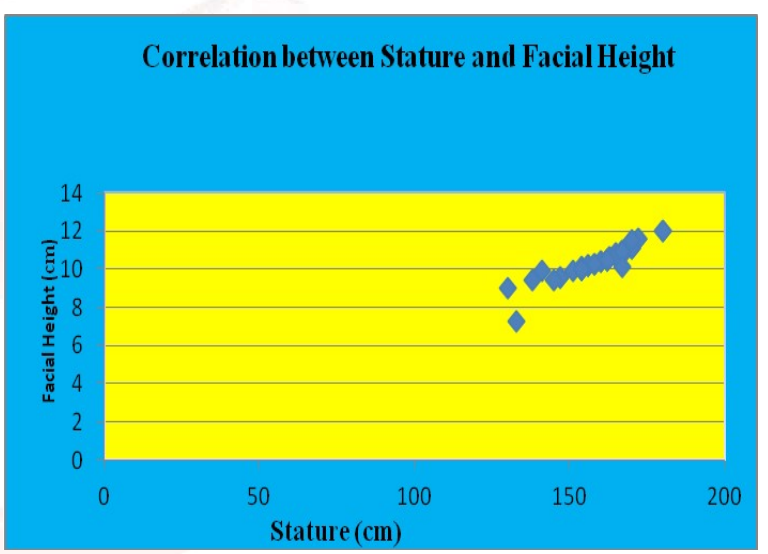

$r=0.93, P<0.001)$ was in accordance with the studies done elsewhere $[3,14,17,18]$.

The mean stature of the subjects of the present study was $158.93 \mathrm{~cm}$ that was dissimilar to the mean stature of the Gujarati male medical students $168.10 \mathrm{~cm}$ [19].

Like the stature, the mean facial height is lesser in this study than a group of Jews, Protestant, Catholic students at Ohio state university U.S.A. Their study observed that Catholics are having greater facial height and are taller in stature than that of Jews and Protestant. This indicates that the anthropometric variations exist among different religions [3].

The positive correlation between the facial height and the stature (Pearson's $r=0.93$ ) was significantly higher than a similar kind of study done in Kabui's males (Pearson's $r=0.21$ ) [14]. The present study was compared with similar studies performed on other populations of 
different ethnic groups of India and the rest of the world.

The mean facial height is $10.38 \mathrm{~cm}$ as shown in Table 4. The mean facial heights of the earlier researches done were higher than the present study. Table 5 shows that the mean facial height of the present study is more than the mean facial height of North Indian Kolis in the study of Krishan and Kumar (2008) and Haryanvi Baniyas in the study of Krishan (2011) where it is less than the present study. So, it is concluded from the present study that the Haryanvi Baniyas and North Indian Kolis have a short facial height in comparison to the mean Indian face length.

The mean value of stature in females in the present study is $158.93 \mathrm{~cm}$. Table 6 also shows in the present study that the mean value of stature is higher than the Srilankans, South Africans and Bangladeshis but is lower than the Northwest Indians studied by Bale et al [19]. The study when compared with Indian studies on the mean values of stature are higher in Haryanvi Baniyas than the Gujarat Population, central Indian Population, Kabuis of Imphal Valley, North Indian Kolis, Northwest Indians and Punjabi populations but lower than the South Indian population, Mysorean population(south Indians), North Indian Gujjars and almost similar to the North Indian population.

In the present study, correlation coefficient ( $r$ ) between stature and facial length in females was 0.298 which is higher than the previous as shown in table 7.

The present work was done on 43 female students of a medical college in Sitapur, Uttar Pradesh. Our aim was to find out a correlation between the facial height and the stature, if any. Subjects with the history of abnormal neurological findings affecting the facial dimensions, oculofacial trauma and craniofacial deformities were excluded from the study. All the collected data were analysed statistically. The mean stature and mean facial height of the female students were found to be $158.9 \mathrm{~cm}$ and 10.39 $\mathrm{cm}$ respectively. These findings were similar to the previous studies. Such trends based on racial or ethnic data are desirable because these trends show the potentiality of craniofacial growth. This potentiality is resulted from ethnic, racial and sexual difference.

Int J Anat Res 2018, 6(2.1):5104-09. ISSN 2321-4287
The present study provides a statistically significant positive correlation between the facial height and the stature. Estimation of the stature in the present study can also be helpful in identification of other personal data like estimation of sex, age, race etc where only head and face are brought for anthropometric examinations. Therefore, the following conclusions can be obtained from the present study:

1. There is a statistically significant positive correlation between the facial height and the stature.

2. Estimation of the stature in the present study can also be helpful in identification of other personal data like estimation of sex, age, race etc.

3. Estimation of stature from the facial height could be performed where only unknown head and face are brought for anthropometric examinations.

\section{ACKNOWLEDGEMENTS}

We are grateful to Honourable Dr. Richa Mishra, Chairperson, Hind Institute of Medical Sciences, Sitapur, Uttar Pradesh (India) for allowing to conduct the present research work in her prestigious institute. The authors are thankful to Prof (Dr.) RR Shukl, Principal of the same institute for his boundless affection, guidance and help. The author is indebted to Prof (Dr.) HA Alvi, Head of Department of Dental Surgery of the same institute for his constant supervision, worthy guidance, masterly advice and generous help throughout the study. The author is also grateful to the medical students who have voluntarily participated.

\section{Conflicts of Interests: None}

\section{REFERENCES}

[1]. Krishan V .Textbook of Forensic Medicine and Toxicology. 4th edition (Elsevier Publishers Reed Elsevier India private Ltd), India.2009: 48-50.

[2]. Wiki, last edited on 13 august 2012, at 3:58

[3]. Yadav SK, Ttimalsina S, Pandey N et al. Correlation of personal height with various cephalometric variables (Head length, Facial height, Bizygomatic arch breadth). International Journal of Innovative and Applied Research. 2015;3(9):5- 8.

[4]. Ozasian et al. Estimation of stature from body parts. Forensic Science International.2003;132(1):40-5. 
[5]. Krishan K .Anthropometry in Forensic Medicine and Forensic Science: Forensic anthropometry. International Journal of Forensic Science. 2007;2(1):1.

[6]. Bhatnager DP, Thaper SP, Bhatish MK .Identification of personal height from the somatometry of the hand in Punjabi male. Forensic Science International $.1984 ; 24(1): 137-41$.

[7]. Kamel et al. Prediction of stature from hand measurement. Forensic Science International. 1990;46(3):181-87.

[8]. Duyar I, Pelin C, Zagyapan R.A new method of stature estimation for forensic anthropological application. Anthropological Science. 2006;114(1):23-7.

[9]. Nagesh KR, Kumar GP. Estimation of stature from vertebral column length in South Indians. Legal Medicine .2006;8:269-72.

[10]. Krishan K, Sharma A. Estimation of stature from dimensions of hands and feet in a North Indian Population. Journal of Forensic and Legal Medicine.2007;14:327-32.

[11]. Smith SL .Stature Estimation of 3-10 year old children from long bone lengths. Journal of Forensic Science. 2007;52:538-46.

[12]. Restogi P, Nagesh KR, Yoganarasimha K .Estimation of stature from hand dimensions of North and South Indians. Legal Medicine.2008;10:185-9.

[13]. Mahajan A, Khurana BS.The study of Cephalic Index in Punjabi students. Journal of Punjab Academy of Forensic Medicine and Toxicology. 2010;10:24-6.
[14]. Jibonkumar, Lilinchandra. Estimation of Stature Using Different Facial Measurements among the Kabui Naga of Imphal Valley, Manipur; Anthropologist. 2006;8(1):1-3.

[15]. Brown JK, Feng J, KnappT R. Is self-reported height or arm span a more accurate alternative measure of height? Clinical Nursing Research. 2002;11(4):417-32.

[16]. Standring S, Ellis H, Healy JC et al. Gray's Anatomy, 39th edition, Edinburgh, Elsevier Churchill Livingstone. 2005.

[17]. Evereklioglu C, Yakinchi C, Hamidi E et al. Normative Values of Craniofacial Measurements in Idiopathic Benign Macrocephalic Children. The Cleft PalateCraniofacial Journal. 2001;38(3):260-263.

[18]. Jadav HR, Shah GV. Determination of personal height from the length of head in Gujarat Region. Journal Anatomical Society India. 2004 53(1):20-21

[19]. Bale et al. Relationship between Head Circumference and Height in Normal Adults and in the Nevoid Basal Cell Carcinoma Syndrome and Neurofibromatosis Type 1. American Journal of Medical Genetics.1991;40:206-10.
How to cite this article:
Kamil Khan, Md Tabrej Alam, Srivastava RK, Kalpana Purohit, Md Shadab Raheel. ADULT STATURE RECONSTRUCTION FROM CEPHALO-FACIAL DIMENSION IN INDIAN FEMALES. Int J Anat Res 2018;6(2.1):5104-5109. DOI: 10.16965/ijar.2018.129 